Golden Gate University School of Law GGU Law Digital Commons

Publications

Faculty Scholarship

$11-7-2011$

\title{
Being Professionally Responsible in Property Transactions
}

\author{
Roger Bernhardt \\ Golden Gate University School of Law, rbernhardt@ggu.edu
}

Follow this and additional works at: http://digitalcommons.law.ggu.edu/pubs

Part of the Property Law and Real Estate Commons

\section{Recommended Citation}

Bernhardt, Roger, "Being Professionally Responsible in Property Transactions" (2011). Publications. Paper 469.

http://digitalcommons.law.ggu.edu/pubs/469

This Article is brought to you for free and open access by the Faculty Scholarship at GGU Law Digital Commons. It has been accepted for inclusion in

Publications by an authorized administrator of GGU Law Digital Commons. For more information, please contact jfischer@ggu.edu. 


\title{
Being Professionally Responsible in Property Transactions Roger Bernhardt and Robert L. Kehr
}

\author{
Fair v Bahktiari
}

Since the last issue, our courts have made two strong statements to real estate attorneys about proper and improper behavior in handling property matters for their clients. In Fair v Bahktiari (2011) 195 CA4th 1135, CR3d _ the court of appeal rejected the fee claims of an attorney who went into business with his client without properly advising him to have another attorney review their relationship. In Oasis $W . v$ Goldman (2011) 51 C4th 811, 124 CR3d 256, the supreme court held an attorney and his law firm liable for switching sides against the former client's best interests. (Both cases are reported separately in this issue.)

Although both of these decisions obviously instruct practicing attorneys to watch and change their office practices, I-being only a law professor (of property law, not legal ethics) and engaged in practice only indirectly - felt hardly qualified to speak on these matters. So I turned to Robert L. Kehr, who testified as the expert witness for Fair on the ethical issues raised in that case, to opine for the rest of us on both decisions.

RB: Does Fair mean that an attorney cannot invest in a business deal with his or her real estate client?

RK: No. The opinion in Fair does not change the rules governing a lawyer who wants to engage in a business transaction with a client, but it is a cautionary tale about what the civil consequences can be for a lawyer who gets it wrong. The lawyer failed to meet his burden of showing that his transactions with his clients were fair and reasonable to the clients, as required by Prob C $\S 16004$. The result was that the lawyer lost his ownership interest in the business (a series of real estate investments in which the lawyer was a 
partner) despite the fact that the lawyer had done years of work as an active partner in the business. The lawyer was permitted to retain all of his prior compensation (which the former clients did not seek to recover), but the lawyer was denied the right to obtain quantum meruit compensation for the services he provided to the investment entities.

RB: Well, what if the lawyer doesn't invest funds into the client's project but instead agrees to take a piece of the action in lieu of fees for doing the legal work for the client?

RK: A lawyer's fee agreement is subject to the business transaction rules when the lawyer obtains an ownership, possessory, or security interest adverse to the client. One example of this is when the lawyer obtains an ownership interest in the client company or in a client's asset as compensation for legal services. The Fair decision does not rely on any distinction between investing with a client and obtaining an ownership interest in return for providing legal services.

Will the Attorney Always Go Unpaid?

RB: Will it always be the result that a lawyer who goes into business with a client will not be able to obtain compensation for services that she or he provides to the client or to the client's business entity?

RK: The answer to that is not entirely certain because the opinion in Fair was based on an aggravated factual situation. Among other things, the lawyer failed to document many of the transactions he sought to enforce, and the parties had disagreed over time as to what their deal was. In addition, the lawyer failed to provide any advice to his clients regarding the transactions despite the continued existence of a lawyer-client relationship, and the lawyer had unresolved conflicts. One conflict was that the lawyer represented multiple clients (including the individual client and numerous business entities) but failed to comply with the conflict disclosure and consent requirements of Cal Rules of Prof Cond 3-310(C). Because of the lawyer's ownership interests, he also had a financial interest in the transactions on which he provided legal advice, but he failed to make the disclosure required by Cal Rules of Prof Cond 3-310(B)(4). Because the situation was extreme, it is possible that a lawyer might succeed in obtaining compensation in other settings, but a lawyer seeking quantum meruit compensation will have an uphill battle. The reason for this is that the court refused to apply the CC §1599 doctrine of severance because the lawyer's failure to prove that the transactions were fair and reasonable permitted the clients to void them in their entirety. The result of voiding the agreements in their entirety was that there was no valid part to be severed from an invalid part. The trial court's key finding was that all of the lawyer's services were "part and parcel of those unenforceable business transactions."

RB: Is there any way for a lawyer to safely go into business with a client and be certain of being able to enforce the compensation features of the deal? 
RK: The safest course is for the lawyer to fully comply with Cal Rules of Prof Cond 3300. Doing so will allow the lawyer to meet the Prob C $\S 16004$ burden of proving that the transaction was fair and reasonable to the client. Compliance means that:

- The agreement will be fully stated in writing in a form that the client reasonably should be able to understand;

- The lawyer advises the client in writing to seek independent counsel and gives the client time to seek that advice;

- The client agrees to the deal in writing; and

- The lawyer provides the client all the advice the lawyer would have given if not a party to the deal.

The obligation to competently advise the client about the transaction long has been part of California law and received its most famous statement in Felton v Le Breton (1892) 92 C 457, 469.

\section{RB: How difficult will that be to do?}

RK: That depends on the nature of the transaction. Imagine, as an example, that a lawyer wants to buy a client's used car for the use of the lawyer's teenager. It would not be complicated for the lawyer to satisfy all of the Cal Rules of Prof Cond 3-300 requirements in an isolated transaction of that sort. The documentation would be simple and the fair value of the used car easy to calculate. The transaction in Fair was pretty far toward the opposite end of the spectrum. There, the lawyer and his client entered into a real estate investment business. Rather than a simple, isolated transaction, the lawyer and client entered into a series of business transactions with one another for which they formed a series of entities over time. Anyone with any real estate experience can picture what this meant in practice because buying, financing, operating, and selling real estate breaks down into a great number of individual transactions. A lawyer in that situation would need to comply with Cal Rules of Prof Cond 3-300 each time the lawyer and client enter into a new transaction with one another or modify an existing agreement. When the lawyer and client work side by side day after day in an active real estate investment or development program, the compliance burden on the lawyer would be extraordinary.

What About Withdrawing as Counsel First?

RB: Would the lawyer be able to avoid these Cal Rules of Prof Cond 3-300 requirements by first terminating the lawyer-client relationship before going into the venture?

RK: That is something for the lawyer to consider, but it has practical problems because the lawyer might have been invited into the real estate project because the lawyer would contribute legal services. This is what happened in Fair. The client testified that he 
agreed to give the lawyer a 30-percent ownership interest because the lawyer was contributing his legal expertise, and the lawyer was found to have represented both the business entities and the individual client thereafter.

RB: If the circumstances allowed the lawyer to end the lawyer-client relationship, would doing that first solve her problem?

RK: It would be a significant protective step for the lawyer to clearly and unambiguously terminate the lawyer-client relationship before entering into any business transaction with a client, and then to carefully avoid any conduct that the former client reasonably might understand to mean that the lawyer-client relationship has been reestablished. However, by itself, that does not provide the lawyer with immunity. The reason for this is that, although Cal Rules of Prof Cond 3-300 by its terms applies to business transactions "with a client," case law has applied it to situations in which the relationship of trust and confidence has continued after the termination of a lawyer-client relationship. This is more likely to occur when the business transaction is related to the subject of the former relationship or involves information that the lawyer obtained as a result of the former representation.

\section{Getting “Independent Approval”}

RB: Tell us about the independent approval requirement. How far does that go? Can the first attorney recommend the name of a second? Must the second be in a different law firm? Who pays the fees of the second attorney?

RK: California Rules of Professional Conduct 3-300 requires the lawyer to recommend to the client that the client seek independent advice, and to give the client time to obtain that advice. In a situation of any complexity or magnitude, such as in Fair, it would be prudent for the lawyer to refuse to proceed unless the client actually obtains independent legal advice. I would apply a common-sense test in determining whether a lawyer is "independent" for purposes of Cal Rules of Prof Cond 3-300. That lawyer should not be in the same law firm with or paid by the first lawyer, and should not have a close personal or professional relationship with the first lawyer that might cause independence to be questioned. It probably would be best if the client were to select the independent lawyer without any input from the first lawyer, but this is not required. California's proposed new Rules of Professional Conduct (on which the supreme court has not yet ruled) have the following explanation:

An independent lawyer is a lawyer who (i) does not have a financial interest in the transaction or acquisition, (ii) does not have a close legal, business, financial, professional or personal relationship with the lawyer seeking the client's consent, and (iii) represents the client with respect to the transaction or acquisition.

RB: Just what is the second attorney supposed to opine about? Can the first attorney inform the second as to the reasons for sending the client to her? 
RK:-To begin, the first lawyer does not "send" the client to the independent counsel. The first lawyer certainly may provide the client with the names of other lawyers to provide needed advice about the proposed transaction, but the first lawyer should not even appear to have selected the second lawyer. Any such suggestion might prevent the second lawyer from being seen as independent. The first lawyer can explain to the second lawyer the reason for the consultation, and it is to be expected that the dealings between the two lawyers might go beyond that. The reason is that the role of independent counsel is to provide competent and unbiased advice about the proposed transaction. For the second lawyer to counsel about the pros and cons of the proposed transaction, and the reasonably available alternatives and their pros and cons, the second lawyer quite likely will want to discuss the situation with the first lawyer to better understand how the nature and form of the proposed transaction were developed. It also is possible that this will lead to negotiations between the two lawyers as to the substance or form of the transaction.

RB: Should the original attorney consult with an ethics expert about the deal while the client is off visiting the independent attorney?

RK: California Rules of Professional Conduct 3-300 sets out a protocol that any lawyer should be able to follow. The greater problem is that the lawyer might not recognize the need to comply with the rule. The Fair situation and others in which I've been involved make it tempting to think that some lawyers are influenced by their personal interests to not recognize the application of Rule 3-300, a requirement that might have been apparent if they were observing the conduct of another lawyer.

Are There Further Obligations Thereafter?

RB: If an agreement is finally worked out and has also been approved by independent counsel, is the original attorney subject to any ongoing further restraints because of his former status?

RK: That will depend on the nature of the transaction. In my earlier example in which a lawyer buys a used car from a client, it is difficult to see how there would be any later interaction between the lawyer and client with respect to that transaction. When a lawyer is in business with a current client, the lawyer must be mindful of the obligation to comply with Cal Rules of Prof Cond 3-300 and Prob C §16004 each time that the lawyer and client enter into a new agreement with one another or modify an existing agreement. The lawyer also must be certain that the business relationship and the lawyer's financial interests do not affect the full performance of all of the lawyer's duties to the client, and must be certain to comply with any other conflict rules that might apply because of multiple clients (Cal Rules of Prof Cond 3-300(C)) or because of the lawyer's financial interest in the subject of his representations (Cal Rules of Prof Cond 3-310(B)(4)).

RB: I saw that the attorney in Fair also was a licensed real estate broker. Could he have taken advantage of that fact in dealing with his client, or did that make his position even more difficult? 
RK: The court in Fair made findings about the lawyer's relative sophistication, and it is possible the court gave some weight to his broker's license, but it is hard to imagine that the outcome would have been any different if the lawyer were not also a broker. The decision hinged on the lawyer's status as a lawyer, his lawyer-client relationships with the individual and with the various entities they formed, and the lawyer's failure to meet the burden of showing that the transactions were fair and reasonable to the clients.

RB: I also saw that it was the client who approached the attorney about the business venture in Fair. Do you think that should bear any weight in deciding what could and couldn't be done?

RK: That point is of minor significance, if any. The bottom line is the lawyer's need to prove that the transaction was fair and reasonable to the client and fully explained.

RB: If Fair's client had sought to also recover what had previously been paid as compensation to Fair, do you think he would have been able to get any back?

RK: I assume that the plaintiffs made a tactical decision in not seeking disgorgement of amounts previously distributed to the lawyer. There is no way of being certain how the trial court would have responded if that claim had been made.

\section{What About Competing Against a Former Client?}

\section{RB: What about, instead, an attorney going into business against a former client? Does Oasis W. v Goldman tell lawyers what they can and cannot do in this respect?}

RK: As a general principle, the duty of undivided loyalty prevents a lawyer from being adverse to a current client on any matter, whether or not related to the subject of the current representation. The opinion in Oasis $W$. is a reminder that the duty of loyalty generally ends with the termination of a lawyer-client relationship. What remains of it after the termination of the lawyer-client relationship is a prohibition on being adverse to the former client with regard to the subject of the former representation. Oasis $W$. also is a reminder that a lawyer may neither use nor disclose the former client's confidential information obtained by the lawyer as a result of the former lawyer-client relationship. What is new in Oasis $W$. is that the narrow continuing duty of loyalty was applied to a lawyer for conduct that did not involve the representation of a new client. This suggests that a lawyer may engage in a business that is competitive with that of a former client, but not if in doing so the lawyer violates either the narrow continuing duty of loyalty or the continuing duty of confidentiality.

RB: Can she join a firm that represents a competitor? 
RK: Yes, but with some important limits. First, without the consent of the former client, a lawyer cannot be adverse to a former client with respect to a matter that is the same or substantially related to a matter on which the lawyer represented the former client. Second, the same is true if the former representation was by the former firm, but not by the lawyer personally, but only if the lawyer while at the former firm obtained confidential information of the former client. Third, the lawyer may not use or disclose confidential information of the former client.

RB: So if an attorney knows when she's leaving her old firm or old client, does she have to advise that client about any adverse potential in her new situation?

RK: No. There is no general requirement that a lawyer who is leaving a law firm must give notice to or obtain consent from a former client when the lawyer's new firm represents the former client's competitor or is adverse to the former client. However, consent from the former client will be needed if the lawyer will be adverse to the former client with respect to the subject of the former representation. Even if the individual lawyer won't be adverse to the former client, the lawyer must be aware that any information held by any firm lawyer is presumed to have been shared with all firm lawyers. This means that if the lawyer has pertinent confidential information, the lawyer's new firm might be subject to disqualification even when the individual lawyer is not adverse to the former client. Under the recent decision in Kirk $v$ First Am. Title Ins. Co. (2010) 183 CA4th 776, 108 CR3d 620, it might be possible to institute an ethics screen to prevent disqualification of the firm when the migrating lawyer brings pertinent confidential information.

RB: If an attorney switches to another firm that presents some potential for conflicts, can you suggest any proper steps for her to take to help her keep out of trouble?

RK: The vital first step is to attempt to identify potential conflicts before the lawyer moves to another firm. The lawyer and the new firm must know of the conflict to be able to manage it.

RB: Any other fears you foresee out there or cautions you want to give the bar?

RK: No two business lawyer-client business transactions are the same, and all together they make up a wide spectrum of situations. At one extreme is a plain-vanilla transaction, the fairness of which is obvious and about which there is little or nothing for the lawyer to explain to the client.-It is hard to imagine there being any civil or disciplinary risk to the lawyer in that kind of situation.-The further one moves across the spectrum, the more difficult it becomes for the lawyer to defend, after the fact, that the transaction was fully explained and fair and reasonable to the client.-A major step along the spectrum occurs when moving from a single transaction to a business relationship, as happens when a lawyer goes into a real estate development or investment relationship with a client. This is something of real risk to the lawyer, and something to be done-if at all—only with great caution. 


\section{RB: Thanks so much, Robert.}

Developer met low standard of showing its causes of action had minimal merit and thus trial court properly denied anti-SLAPP motion, which related to attorney's activity to defeat same development project he previously had been retained to support.

Oasis W. Realty, LLC v Goldman (2011) 51 C4th 811, 124 CR3d 256

Developer hired Attorney, who was respected and followed in the community, to assist in getting City approval of a redevelopment project encompassing a five-star hotel and luxury condominiums. Developer retained Attorney on January 26, 2004, and Attorney acted as Developer's key representative in dealings with City. In April 2006, however, Attorney terminated representation. Two years later, in April 2008, City certified the environmental impact report and was poised to approve the redevelopment project. On May 12, 2008, City did approve the project, but on or about that same date, Attorney canvassed his neighbors in an attempt to put a proposition on the ballot opposing that same redevelopment project. On May 14, 2008, after having retained different outside counsel, Developer wrote to Attorney's law firm protesting his actions and demanding that he quit his work to defeat the project. The law firm responded, saying it would take the matter under advisement but would cease all activities adverse to the project in the meantime. Developer then requested that Attorney take immediate "remedial action," essentially retracting his and his wife's statements and letters against the project.

On November 2, 2008, the voters narrowly ratified City’s approval of the project. On January 30, 2009, Developer sued Attorney and his law firm for breach of fiduciary duty, professional negligence, and breach of contract, seeking damages in excess of \$4 million. Attorney brought an anti-strategic lawsuit against public participation (anti-SLAPP) motion under CCP $\S 425.16(\mathrm{~b})(1)$, which the trial court denied, finding no protected activity was involved. The court of appeal reversed and the supreme court reversed again, affirming the trial court judgment on other grounds.

A court evaluates an anti-SLAPP motion in two steps:

- The court determines whether the challenged cause of action is one "arising from" protected free speech or petition rights.

- If protected activity is involved, the court must consider whether the plaintiff has shown a probability of prevailing on the claim.

Here, however, the supreme court jumped directly to the second step because of its "inherent, primary authority over the practice of law.” The court rejected defendants' and the court of appeal's claim that an attorney violates his or her ethical duties only when the attorney has (1) accepted concurrent or successive representation that is substantially related to the prior representation and is adverse to the former client or (2) disclosed confidential information obtained during his or her representation of the former client. The court inferred that Attorney did violate his duty of loyalty by using confidential information because, before or on his retention, Attorney had not advised Developer about any personal relationship or interest that he knew or reasonably should have known could substantially affect the exercise of his professional judgment in the matter-as he would have been obligated to do under Cal Rules of Prof Cond 3310(B). Because he did not do so, it was "reasonable to infer that [Attorney's] opposition to the project developed over the course of the representation, fueled by the confidential information he gleaned during it.” 51 C4th at 822.

As to the argument that the First Amendment protected Attorney’s speech, defendants provided no authority that would extend to "protect such duplicity." An attorney must subordinate his or her personal interests while acting in a professional capacity if the loyalty owed to a client would be violated. Developer met the low standard of showing its causes of action had minimal merit; the anti-SLAPP motion was properly denied.

Attorney who entered into business agreements with client without meeting written client disclosure and consent requirements of Cal Rules of Ct 3-300 breached his fiduciary duty to client under Prob C §16004(c). Business agreements were voidable at client’s election and, due to seriousness of breach, attorney was barred from quantum meruit recovery.

Fair v Bakhtiari (2011) 195 CA4th 1135, __ CR3d _ _ 
After inheriting substantial sums, Client entered into a business arrangement with Attorney. Ultimately, Attorney set up three "Stonesfair" corporations. The parties established Attorney's ownership interests in the corporations at 30 percent, 27.5 percent, and 5 percent, representing the value of Attorney’s services. Notably, Attorney did not explain (or establish) many material terms and conditions for the business transactions. This failure resulted in a "constant source of debate and disagreement throughout the course of their business relationship and contributed to its demise." 195 CA4th at 1143. Both Attorney and Client brought suit; the cases were consolidated. Although evidence established that each of the three business transactions was "fair and reasonable" and that one Stonesfair entity had been "tremendously successful," the trial court held that Attorney had fatally violated disclosure and consent duties under Cal Rules of Ct 3-300. Given the serious conflict of interest this created under Prob C $\$ 16004$ (which applies to the attorney-client relationship), Client properly voided the agreements and Attorney was precluded from seeking any quantum meruit recovery of back-end interests and profits from the investments. The court of appeal affirmed.

Attorney violated both Cal Rules of Ct 3-300 and Prob C §16004, which is a statutory complement to the rule. Rule 3300 requires that an attorney who contemplates entering into a business relationship with a client must ensure that:

- Agreement terms are fair and reasonable and understood by client;

- Client is advised in writing to seek advice from independent counsel and given time to do so; and

- Client consents in writing to the terms of the agreement.

Even if the client suffers no damage, an attorney may violate the rule. Under Prob C $\$ 16004(\mathrm{c})$, an attorney who obtains an advantage from his or her client is presumed to be in violation of fiduciary duties. The advantage need not be unfair-here, Attorney's improved financial position and his substantial gain, benefit, and profits triggered the undue influence presumption. Attorney could not rebut that presumption, particularly when so many material agreement terms were disputed between Attorney and Client. Attorney should have given Client advice against his interests as if he were a third party.

Attorney could not sever a "myriad of services" from the voided agreements to claim a quantum meruit recovery. Because the court held the agreements voidable and unenforceable, there was "no lawful portion of the agreements" that could be severed and legally claimed under quantum meruit, particularly since those services were rendered after the breach of fiduciary duty. Substantial evidence supported a finding that Attorney's "conduct here was so fundamentally at war with rule 3-300 and section 16004, that it infected the entire [business] relationship ... and that [Attorney's] breach of his fiduciary duties under the statute was therefore sufficiently serious as to warrant the denial of quantum meruit recovery.” 195 CA4th at 1169. 